\title{
Voltage-Gated Calcium Influx Modifies Cholinergic Inhibition of Inner Hair Cells in the Immature Rat Cochlea
}

\author{
Stephen Zachary, ${ }^{1,2}$ @Nathaniel Nowak, ${ }^{1,2}$ @Pankhuri Vyas, ${ }^{1}$ - Luke Bonanni, ${ }^{1}$ and $\odot$ Paul Albert Fuchs ${ }^{1}$ \\ ${ }^{1}$ The Center for Hearing and Balance, Department of Otolaryngology-Head and Neck Surgery and ${ }^{2}$ Department of Neuroscience, Johns Hopkins University \\ School of Medicine, Baltimore, Maryland 21205
}

Until postnatal day $(\mathrm{P})$ 12, inner hair cells of the rat cochlea are invested with both afferent and efferent synaptic connections. With the onset of hearing at P12, the efferent synapses disappear, and afferent (ribbon) synapses operate with greater efficiency. This change coincides with increased expression of voltage-gated potassium channels, the loss of calcium-dependent electrogenesis, and the onset of graded receptor potentials driven by sound. The transient efferent synapses include near-membrane postsynaptic cisterns thought to regulate calcium influx through the hair cell's $\alpha 9$-containing and $\alpha 10$-containing nicotinic acetylcholine receptors. This influx activates small-conductance $\mathrm{Ca}^{2+}$-activated $\mathrm{K}^{+}$(SK) channels. Serial-section electron microscopy of inner hair cells from two 9-d-old (male) rat pups revealed many postsynaptic efferent cisterns and presynaptic afferent ribbons whose average minimal separation in five cells ranged from 1.1 to $1.7 \mu \mathrm{m}$. Efferent synaptic function was studied in rat pups (age, 7-9 d) of either sex. The duration of these SK channel-mediated IPSCs was increased by enhanced calcium influx through L-type voltage-gated channels, combined with ryanodinesensitive release from internal stores-presumably the near-membrane postsynaptic cistern. These data support the possibility that inner hair cell calcium electrogenesis modulates the efficacy of efferent inhibition during the maturation of inner hair cell synapses.

Key words: calcium-activated potassium channel; calcium-induced calcium release; efferent inhibition; L-type calcium channel; ribbon synapse; synaptic cistern

\section{Significance Statement}

Strict calcium buffering is essential for cellular function. This problem is especially acute for compact hair cells where increasing cytoplasmic calcium promotes the opposing functions of closely adjoining afferent and efferent synapses. The near-membrane postsynaptic cistern at efferent synapses segregates synaptic calcium signals by acting as a dynamic calcium store. The hair cell serves as an informative model for synapses with postsynaptic cisterns (C synapses) found in central neurons.

\section{Introduction}

Before the onset of hearing, both efferent and afferent neurons innervate inner hair cells (IHCs). The cholinergic efferent synapses produce inhibition through the combined activity of $\alpha 9$ containing and $\alpha 10$-containing nicotinic acetylcholine (ACh) receptors ( $\alpha 9 \alpha 10$-nAChRs) and associated calcium-dependent potassium channels (Glowatzki and Fuchs, 2000), as occurs at the

Received Jan. 26, 2018; revised May 14, 2018; accepted May 16, 2018.

Author contributions: S.Z., N.N., and P.A.F. designed research; S.Z., N.N., and P.A.F. performed research; S.Z., N.N., P.A.F., P.V., and L.B. analyzed data; S.Z., P.V., N.N., and P.A.F. wrote the paper.

This work was supported by National Institute on Deafness and Other Communication Disorders Grants R01 DC001508 (P.A.F.), R01 DC015309 (R. Winslow and P.A.F.), and T32 DC000023 (N.N.); the John E. Bordley Professorship (P.A.F.); and the David M. Rubenstein Fund for Hearing Research. We thank Drs. H. Hiel and M. Lehar for cochlear histology and electron microscopy.

The authors declare no competing financial interests.

Correspondence should be addressed to Paul Albert Fuchs, The Center for Hearing and Balance, OtolaryngologyHead and Neck Surgery, The Johns Hopkins University School of Medicine, 720 Rutland Avenue, Ross 818, Baltimore, MD 21205. E-mail: pfuchs1@jhmi.edu.

DOI:10.1523/JNEUROSCI.0230-18.2018

Copyright $\odot 2018$ the authors $\quad 0270-6474 / 18 / 385677-11 \$ 15.00 / 0$ mature synapse on outer hair cells (OHCs; Housley and Ashmore, 1991; Evans, 1996; He and Dallos, 1999; Oliver et al., 2000; Lioudyno et al., 2004; Ballestero et al., 2011) and in hair cells of nonmammalian vertebrates (fish: Flock and Russell, 1976; frog: Ashmore and Russell, 1982; Sugai et al., 1992; turtle: Art et al., 1984; and chicken: Fuchs and Murrow, 1992). However, the calcium signals that give rise to cholinergic inhibition in any hair cell are not fully understood. Likewise, the determinants of synaptic connectivity that vary between hair cell types also are not known. The intermingling of efferent and afferent contacts on immature IHCs offers an opportunity to probe the roles of calcium influx and efferent synaptic cisterns as intermediaries in activity-dependent (calcium-dependent) synaptic maturation. This work asks whether voltage-gated calcium influx can load the synaptic cistern to modify the efficacy of cholinergic synaptic inhibition of immature IHCs. The results provide the most direct evidence to date that the cistern can serve as a dynamic synaptic calcium store.

The efferent-IHC synapse is well characterized in terms of its development, molecular components, and physiological proper- 
ties (Simmons, 2002). Efferent synapses first become evident at postnatal day (P) 1, are ubiquitous by $\mathrm{P} 3$, reach an average of 16 per IHC by P8 (Roux et al., 2011), and then disappear completely after P16 (Simmons et al., 1996; Katz et al., 2004). Efferent synapses on immature IHCs have low release probabilities (Goutman et al., 2005; Zorrilla de San Martín et al., 2010) that can be modulated by a variety of mechanisms, including retrograde facilitation by nitric oxide (Kong et al., 2013), enhancement by metabotropic glutamate receptors (Ye et al., 2017), or suppression by metabotropic GABA receptor activity (Wedemeyer et al., 2013). The IHC responds to efferent transmitter release via $\alpha 9 \alpha 10$-nAChR gating, which produces an influx of $\mathrm{Ca}^{2+}$ ions and the subsequent gating of small-conductance calcium-dependent (SK) channels (Glowatzki and Fuchs, 2000). Efflux through SK channels hyperpolarizes and shunts the IHC. Because of this twochannel arrangement, efferent IPSCs have biphasic waveforms near the resting potential, consisting of a brief inward current through $\alpha 9 \alpha 10$-nAChRs and a longer-lasting outward current mediated by SK channels.

Like those of the mature efferent contacts on OHCs, efferent contacts on immature IHCs have associated near-membrane postsynaptic cisterns (Pujol et al., 1978, 1979; Shnerson et al., 1981). These cisterns could play a role in efferent synaptic calcium regulation in IHCs as they are thought to do in OHCs (Dallos et al., 1997; Sridhar et al., 1997; Lioudyno et al., 2004). Unlike the mature connections of OHCs, however, transient efferent synapses are intermingled with many afferent ribbons and their associated voltage-gated calcium-channel clusters that become the permanent synaptic features of the IHC.

In the immature cochlea, spontaneous waves of ATP release from cells of Kolliker's organ pattern repetitive, overshooting calcium action potentials that occur spontaneously in IHCs (Tritsch et al., 2007; Johnson et al., 2011). IHC activity in turn drives bursting activity of type-I afferents that may be required for refinement of central connectivity (Tritsch et al., 2010; Johnson et al., 2011; Clause et al., 2014). With the onset of hearing, calcium currents become smaller but evoke transmitter release more efficiently (Johnson et al., 2005, 2009; Wong et al., 2013). These developmental changes in calcium electrogenesis may not only drive activity-dependent maturation of synapses centrally, but also peripherally; i.e., the loss of efferent contacts and the stabilization of afferent contacts on cochlear IHCs.

\section{Materials and Methods}

Procedures for killing animals and tissue collection were approved by the Johns Hopkins Institutional Animal Care and Use Committee. Following deep isoflurane anesthesia, Sprague Dawley (Charles River Laboratories, http://www.criver.com/) rat pups (P7-P9 of either sex) were decapitated and the temporal bone removed for hair cell recording in excised cochlear tissue. Experimental drugs were obtained from Tocris Bioscience.

Electron microscopy. Cardiac perfusion with fixative was performed during deep pentobarbital anesthesia. Temporal bones were excised and immersed in fixative and then processed according to published methods (Fuchs et al., 2014). Tissue was obtained from two male P9 Sprague Dawley rats (Charles River Laboratories, http://www.criver.com/). Euthanasia and tissue extraction were performed under an approved animal protocol (Johns Hopkins Institutional Animal Care and Use Committee). Tissue was fixed with $1 \%$ osmium $(\mathrm{OsO} 4)$ and $1 \%$ potassium ferricyanide [FeK3(CN)6] in $0.1 \mathrm{~m}$ sym-collidine- $\mathrm{HCl}$ buffer, $\mathrm{pH}$ 7.4, rinsed with $0.1 \mathrm{~m}$ maleate buffer, $\mathrm{pH} 7.4$, in 5\% EDTA in $0.1 \mathrm{~m}$ phosphate buffer, $\mathrm{pH}$ 7.4-7.8. Tissues were embedded in Araldite and then cut into $40 \mu \mathrm{m}$ sections parallel to the modiolus. These thick sections were re-embedded in Epon between Aclar sheets (Electron Microscopy Sciences) and desired cochlear segments cut out for thin sectioning. Chosen sections were re-embedded in Epon blocks for ultrathin sectioning (Leica Ultracut S) parallel to the modiolar axis (perpendicular to the organ of Corti). Serial $65 \mathrm{~nm}$ sections were collected onto Formvar-coated slot grids for image acquisition on a Hitachi H7600 transmission electron microscope at 80 $\mathrm{kV}$ at $30,000 \times$ magnification. Digital images $(2120 \times 2120$ pixels $)$ were collected at 8-bit or 16-bit depth and analyzed as 8-bit files. Images were imported into Reconstruct software (Fiala, 2005; RRID:SCR_002716) for assembly, calibration, and alignment. Outlines were traced of the hair cell, the efferent contacts and the associated postsynaptic cistern, the afferent contacts and associated synaptic ribbons, and the vesicle clusters. Three IHCs from one animal and two from another were serially sectioned and reconstructed. Approximately 3000 synaptic vesicles in six efferent terminals contacting three IHCs were outlined with the ellipse drawing tool in Reconstruct. The diameter of each vesicle was recorded as that of an equivalent circle derived from the area of each ellipse. This approximation was used to estimate vesicle volumes in the 65 -nm-thick sections (average vesicle diameter, $\sim 40 \mathrm{~nm}$ ).

Electrophysiology. Apical cochlear turns were microdissected and placed in a recording chamber mounted on a Zeiss Axioskop 2 fluorescence microscope and kept at room temperature. The preparation was bathed in external solution containing the following (in $\mathrm{mm}$ ): $2.5 \mathrm{KCl}$, $148 \mathrm{NaCl}, 1.3 \mathrm{CaCl}_{2}, 0.9 \mathrm{MgCl}_{2}, 0.7 \mathrm{NaH}_{2} \mathrm{PO}, 5.6 \mathrm{D}$-glucose, and 10 HEPES, pH 7.4. Hair cells were visualized via a $40 \times$ water-immersion objective using differential interference contrast optics.

Recording pipettes had resistances of 3-6 $\mathrm{M} \Omega$ and were filled with internal solution containing the following (in $\mathrm{mM}$ ): $135 \mathrm{KCl}, 3.5 \mathrm{MgCl}_{2}$, $0.1 \mathrm{CaCl}_{2}, 5$ EGTA, 5 HEPES, and 2.5 Na-ATP, pH 7.2. Series resistance after rupture of the gigaohm seal ranged from 10 to $20 \mathrm{M} \Omega$ and was not compensated for the small membrane currents recorded here. Voltageclamp time constants ranged therefore from 100 to $200 \mu$ s (assuming average input capacitance of $10 \mathrm{pF}$ ). Electrical stimulation of efferent axons was delivered via silver wire inserted into a glass micropipette with a diameter of $20-30 \mu \mathrm{m}$ and a return wire inserted in the bath. This pipette was positioned $\sim 20 \mu \mathrm{m}$ modiolar to the base of an IHC subjected to tight-seal whole-cell voltage-clamp recording. The pipette position was adjusted until current flow through it evoked postsynaptic currents in the IHC under study. An electrically isolated constant current source (Digitimer, model DS3) was triggered manually while scanning for active efferents and at $1 \mathrm{~Hz}$ under software control thereafter. Efferent axons were stimulated via pulses of $\sim 50-100 \mu \mathrm{A}, 30-300 \mu$ s duration. Evoked and spontaneous IPSCs were analyzed.

Experimental design and statistical analysis. For morphological analysis, five IHCs from the cochleas of two rats were serially sectioned in their entirety, resulting in $>100$ sections in each case. Synaptic profiles were delineated and parameters compiled in Table 1. No statistical analyses were performed on these data, which provide a basic description of synaptic organization in immature IHCs equivalent in age to those used in physiological recordings. For intracellular recording, hair cell membrane currents were obtained with a Multiclamp 700B amplifier (Axon) and analyzed using pClamp (Axon, RRID:SCR_011323), MiniAnalysis (Synaptosoft, RRID:SCR_002184), Origin Pro (OriginLab, RRID:SCR_015636), and Excel (Microsoft). Hundreds of synaptic events from each of several hair cells in each experimental condition were pooled to assess effects of membrane potential or drug application on event waveform. Statistical tests were performed with GraphPad Prism 4 (GraphPad Software, RRID:SCR_002798) or the Excel data analysis toolkit. Statistical comparisons were made with unpaired $t$ tests for unequal variances unless otherwise noted. $T$ statistics and $p$ values are reported as $t$ (degrees of freedom), $p$ in figure legends. $P$ values $<10^{-6}$ are reported as $\ll 0.001$. Box-and-whisker plots represent the 75 th, 50th, and 25 th quartiles (box lines) and mean and SDs (mean by marker, SD by whiskers). Summarized control data from Figure 5 are shown for purpose of comparison in Figures 6, 7, and 8.

\section{Results}

\section{IHC synaptic contacts}

Serial section electron microscopy was used to reconstruct synaptic contacts on five IHCs from the apical cochleas of two immature (P9) rats. At this age, there are numerous afferent and 
Table 1. Synaptic morphology in young (P9) rat IHCs (mean \pm SD)

\begin{tabular}{|c|c|c|c|c|c|}
\hline Cell & $030315 \# 1$ & $030315 \# 2$ & $011917 \# 1$ & $011917 \# 2$ & $011917 \# 3$ \\
\hline Section start & 1 & 237 & 3 & 133 & 280 \\
\hline Section stop & 112 & 377 & 109 & 270 & 393 \\
\hline Section\#s & 38 & 125 & 93 & 138 & 133 \\
\hline$z$-depth@65nm ( $\mu \mathrm{m})$ & 7.3 & 9.1 & 6.9 & 8.9 & 8.6 \\
\hline Efferent \# & 16 & 34 & 33 & 34 & 29 \\
\hline Cistern \# & 16 & 34 & 33 & 34 & 29 \\
\hline Afferent\# & 25 & 19 & 19 & 16 & 12 \\
\hline Ribbon \# & 19 & 25 & 20 & 26 & 28 \\
\hline Cistern contact area mean $\left(\mu \mathrm{m}^{2}\right)$ & $0.20 \pm 0.12$ & $0.18 \pm 0.1$ & $0.14 \pm 0.06$ & $0.19 \pm 0.13$ & $0.18 \pm 0.10$ \\
\hline Efferent contact area mean $\left(\mu \mathrm{m}^{2}\right)$ & $0.61 \pm 0.31$ & $0.54 \pm 0.33$ & $0.27 \pm 0.16$ & $0.45 \pm 0.35$ & $0.48 \pm 0.51$ \\
\hline Cistern/efferent area contact ratio & 0.37 & 0.41 & 0.51 & 0.41 & 0.37 \\
\hline Efferent contact area sum $\left(\mu \mathrm{m}^{2}\right)$ & 9.69 & 17.72 & 9.00 & 16.11 & 14.03 \\
\hline Cistern contact area sum $\left(\mu \mathrm{m}^{2}\right)$ & 2.72 & 6.22 & 4.56 & 6.32 & 5.23 \\
\hline Afferent contact area mean $\left(\mu \mathrm{m}^{2}\right)$ & $7.19 \pm 6.41$ & $5.07 \pm 2.29$ & $3.88 \pm 3.79$ & $6.34 \pm 3.77$ & $8.37 \pm 6.87$ \\
\hline Afferent contact area sum $\left(\mu \mathrm{m}^{2}\right)$ & 107.35 & 91.37 & 73.72 & 101.5 & 100.5 \\
\hline Cistern-to-ribbon minimal separation $(\mu \mathrm{m})$ & $1.67 \pm 0.72$ & $1.48 \pm 1.00$ & $1.36 \pm 1.01$ & $1.49 \pm 0.73$ & $1.07 \pm 0.57$ \\
\hline Hair cell surface area in images $\left(\mu \mathrm{m}^{2}\right)$ & 454.09 & 523.7 & 292.4 & 353.6 & 306.7 \\
\hline Efferent $\%$ area & $2.1 \%$ & $3.4 \%$ & $3.1 \%$ & $4.5 \%$ & $4.3 \%$ \\
\hline Afferent $\%$ area & $23.6 \%$ & $17.4 \%$ & $25.0 \%$ & $28.7 \%$ & $32.8 \%$ \\
\hline
\end{tabular}

Synaptic ultrastructure of IHCs from two P9 rats ( 030315 and 011917$)$. Approximately 100 serial sections ( $65 \mathrm{~nm}$ nominal thickness) were assembled [6-12 individual images ( $30,000 \times)$ formed a montage for each section], aligned, and segmented for each of five IHCs. "Contact area" was computed from the $x$-y extent in each section, multiplied by section thickness, and summed through thez-axis. "Cistern-to-ribbon minimal separation" is the average and SD for all cistern s in a given IHC. Summed contact area for all afferents and all efferents was compared to the surface area of each IHC stack to compute percentage area. Averages for afferent-to-efferent and ribbon-to-ribbon separation for the first three cells was reported previously (Moglie et al., 2018). N.B., cell 030315 \#1 included only every third section (approximately).

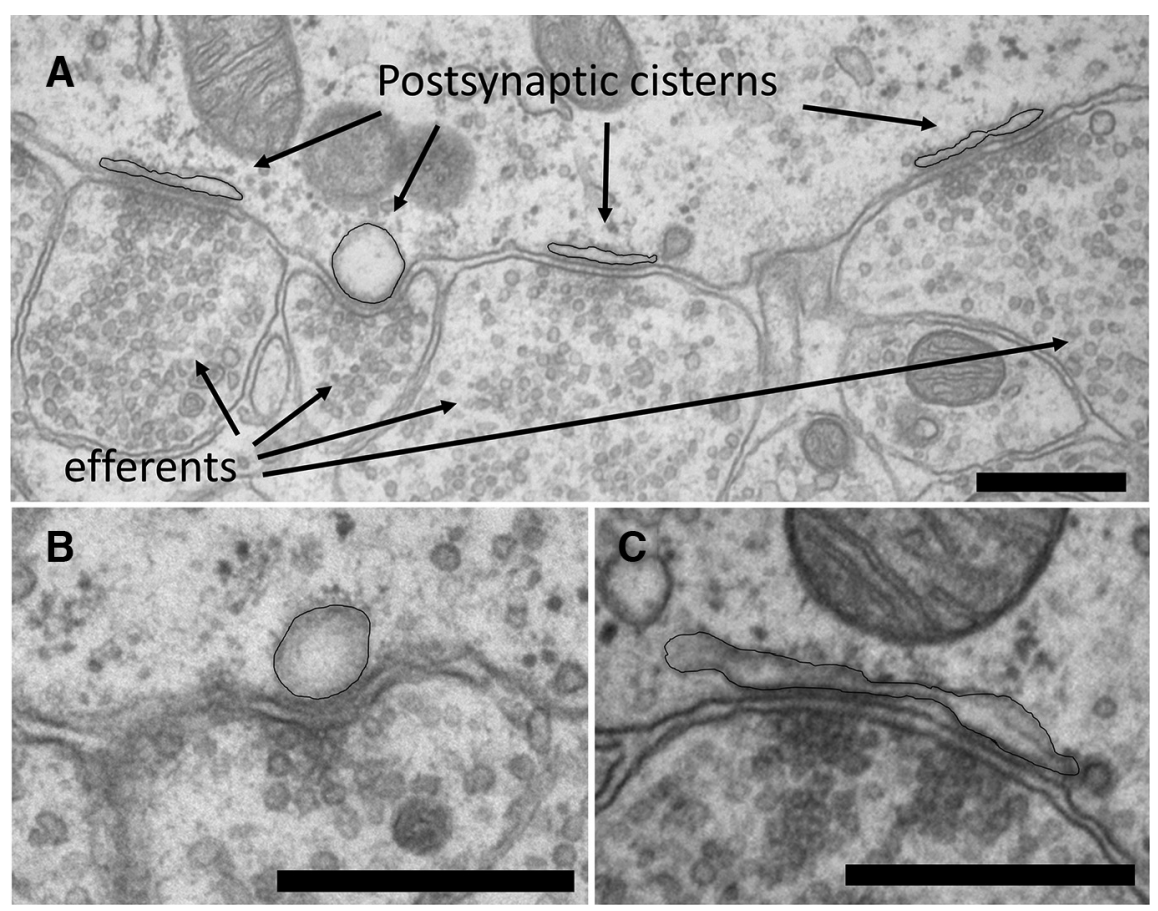

Figure 1. Electron micrographs of efferent synapses on an IHC from apical turn of a P9 rat cochlea. $A$, A cluster of four vesicle-rich efferent terminals and associated postsynaptic cisterns (black outline added). $\boldsymbol{B}$, Another example of an "inflated" postsynaptic cistern at an efferent synapse contact from a different IHC. Sequential sections show these to be spherical, rather than cylindrical. Note the cluster of vesicles suggesting a presynaptic active zone. $\boldsymbol{C}$, Another example of a postsynaptic cistern illustrating the interrupted attachment to the plasma membrane. Note that presynaptic vesicles cluster preferentially opposite the cisternal attachments. Scale bars, $500 \mathrm{~nm}$.

efferent contacts on each IHC (Table 1). Each efferent terminal contact was $\leq 1 \mu \mathrm{m}$ in maximum extent, with an average contact area of $0.2-0.6 \mu \mathrm{m}^{2}$. Associated postsynaptic cisterns were smaller $\left(\leq 0.2 \mu \mathrm{m}^{2}\right)$ than the efferent terminals, and variably shaped, ranging from flat to rounded (Fig. $1 A-C$ ). Cisterns adhered tightly to the IHC plasma membrane for at least some part of their length. For several cisterns, where the cisternal and plasma membranes were both well visualized in orthogonal sections, the average gap distance was $15 \mathrm{~nm}$ ( \pm 2 SDs). Vesicles in the efferent terminal aligned with the tight contact of the cistern. If the cistern gapped away from the plasma membrane, there were fewer vesicles at that point in the efferent terminal (Fig. 1C).

In comparison, afferent contacts were not abundantly vesiculated (Fig. 2A-C) and were substantially larger in contact area (ranging from $\sim 3$ to $\sim 8 \mu \mathrm{m}^{2}$ ) and were fewer in number than efferent boutons (range, 12-25; Table 1), but could be associated with $>1$ ribbon (Fig. $2 B$ ). Some afferent contacts extended up to $8 \mu \mathrm{m}$ along the side of the IHC. Ribbons were $<200$ nm wide, variably shaped, and associated with large clouds of small clear vesicles (Fig. 2). In addition to ribbonassociated vesicle clouds, afferent contacts were postsynaptic to near-membrane vesicle clusters that did not include a visible ribbon in sequential sections (Fig. 2C). Similar-appearing vesicle clouds could be found elsewhere in the cytoplasm at some distance from the plasma membrane.

Afferent and efferent synaptic contacts were mapped in five nearly or completely reconstructed IHCs from two P9 rats, three illustrated in Figure 3. From 16 to 34 efferent synaptic contacts on individual IHCs were identified by the juxtaposition of a cistern with vesicle clusters in an efferent terminal contacting the IHC at that point (Table 1). Afferent contacts (12-25; Table 1) were distinguished by their relatively homogenous cytoplasm, larger size, and association with presynaptic ribbons. To gauge the potential for functional interactions, the distance between every cistern and ribbon was determined for each IHC. The dis- 
tance to the nearest ribbon was then averaged for each cistern of a given cell as reported in Table 1. This average minimal distance between an efferent cistern and a ribbon ranged from 1.07 to $1.67 \mu \mathrm{m}$ for these five IHCs. A preliminary estimate of the average minimal distance $(1.57 \mu \mathrm{m})$ between cisterns and ribbons was given previously for three of these cells (Moglie et al., 2018).

\section{Voltage-gated calcium influx enhances membrane current evoked by ACh The close intermingling suggests that voltage-gated calcium influx at presynap- tic active zones could influence calcium- dependent efferent inhibition of the IHC. Since shock-evoked IPSCs occur infre- quently, an initial test was made using a puffer pipette for brief application of ACh interspersed with voltage steps to -20} $\mathrm{mV}$, the peak of the current-voltage relation of the hair cell's L-type calcium current. ACh was puffed (5-50 ms duration) repeatedly while positioning the pipette near the IHC until postsynaptic responses were consistent in amplitude and time course.

ACh evoked a control current consisting of a brief inward and longer-lasting outward current at $-60 \mathrm{mV}$. After a pause of $2 \mathrm{~s}$, the membrane potential was stepped to $-20 \mathrm{mV}$ for $5 \mathrm{~s}$; ACh was puffed again $2 \mathrm{~s}$ after stepping the voltage back to $-60 \mathrm{mV}$. This prolonged depolarization is similar to the time course of spontaneous depolarizations and bursts of calcium spikes observed in IHCs before the onset of hearing (Tritsch et al., 2007). Preliminary experiments using briefer steps ( 0.5 or $2 \mathrm{~s}$ ) gave less consistent results. The time between puffs and voltage steps allowed the IHC membrane current to return to baseline. Every other protocol included the same ACh application without a voltage step separating the responses.

Exemplar membrane current responses to these protocols are shown in Figure $4 A$. In protocols where a depolarizing voltage step was applied, the peak amplitude and duration of AChevoked current were increased compared with those of responses that preceded the voltage step. The amplitude and time course changes together produced a response area that was $\sim 40 \%$ larger than that of the control response (Fig. 4C). When ACh puffs were applied with the same timing, but without an intervening depolarization, there was no change in amplitude or time course, as seen in the average ratio of response areas (Fig. $4 A, C$, bottom record and box plots). In the presence of $10 \mu \mathrm{M}$ nimodipine to inhibit L-type $\left(\mathrm{Ca}_{\mathrm{v}} 1.3\right)$ voltage-gated calcium channels, voltage steps to $-20 \mathrm{mV}$ had no significant effect on subsequent responses to a brief puff of ACh (Fig. 4B,D). As before, control responses with identical timing but without intervening voltage steps were unchanged, ruling out desensitization or undefined rundown as an alternative explanation. These effects show that influx of calcium through L-type $\left(\mathrm{Ca}_{\mathrm{v}} 1.3\right)$ voltage-gated channels can enhance the impact of cholinergic inhibition due to exogenous ACh. Does this mechanism also affect the much briefer and smaller postsynaptic currents evoked by vesicular $\mathrm{ACh}$ release from the efferent terminal?

\section{Efferent IPSCs in P7-P9 rat IHCs}

Electrical stimulation evoked efferent transmitter release during whole-cell gigaohm-seal recordings from P7-P9 rat IHCs. Both evoked and spontaneous IPSCs were recorded and analyzed. Ef-
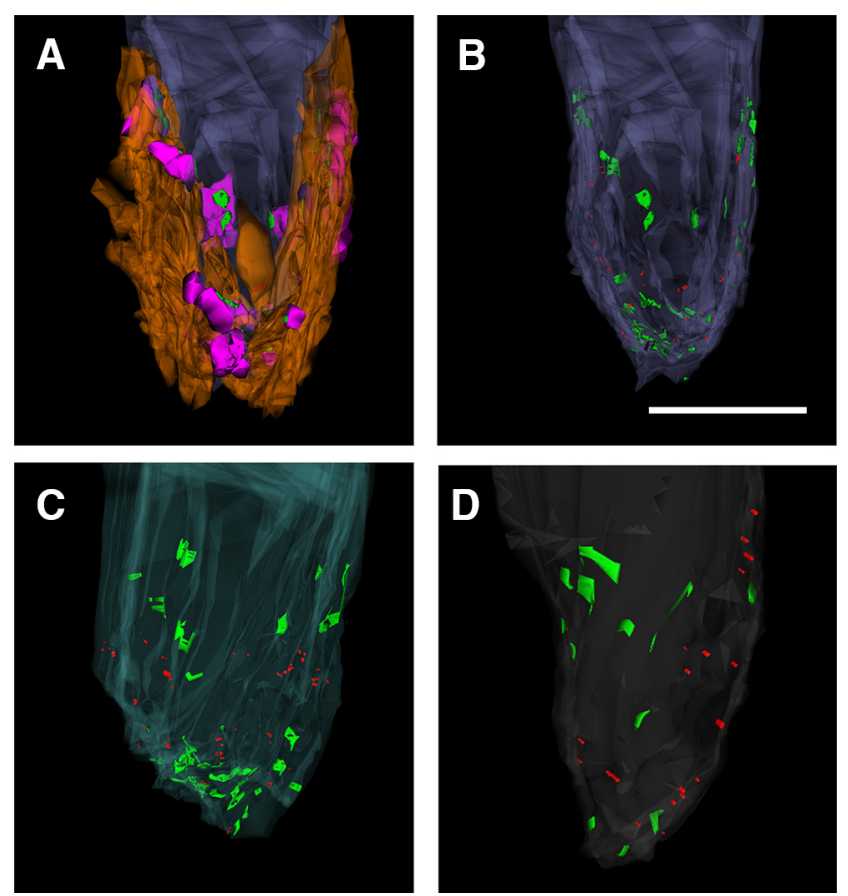

Figure 3. $\mathrm{P} 9$ rat IHCs reconstructed from serial EMs. $\boldsymbol{A}$, Fourth cell from Table 1. Afferents in brown; efferents in magenta. $\boldsymbol{B}$, Same cell as $\boldsymbol{A}$, neurons removed, postsynaptic cisterns in green, ribbons in red. $\boldsymbol{C}$, Fifth cell from Table 1, same color scheme for synaptic structures as in $\boldsymbol{B}$. $\boldsymbol{D}$, First cell from Table 1; different animal, same color scheme for synaptic structures as $\boldsymbol{B}$ and $\boldsymbol{C}$. Scale bars, $5 \mu \mathrm{m}$.

ferent transmitter release occurred infrequently during $1 \mathrm{~Hz}$ electrical stimulation. Given the numerous efferent contacts on each IHC (Table 1), this implies that the quantum content of individual terminals is very much $<1$, which is consistent with marked facilitation of these synapses (Goutman et al., 2005). Thus, spontaneous or evoked IPSCs should result from the release of ACh contained in single vesicles and therefore be relatively uniform in size and shape in these compact, isopotential IHCs.

The reality, however, was somewhat different. IPSCs mediated by outward flux through calcium-dependent SK channels were variable in amplitude and time course (Fig. 5). The amplitude and waveform distributions at $-40 \mathrm{mV}$ were not symmet- 


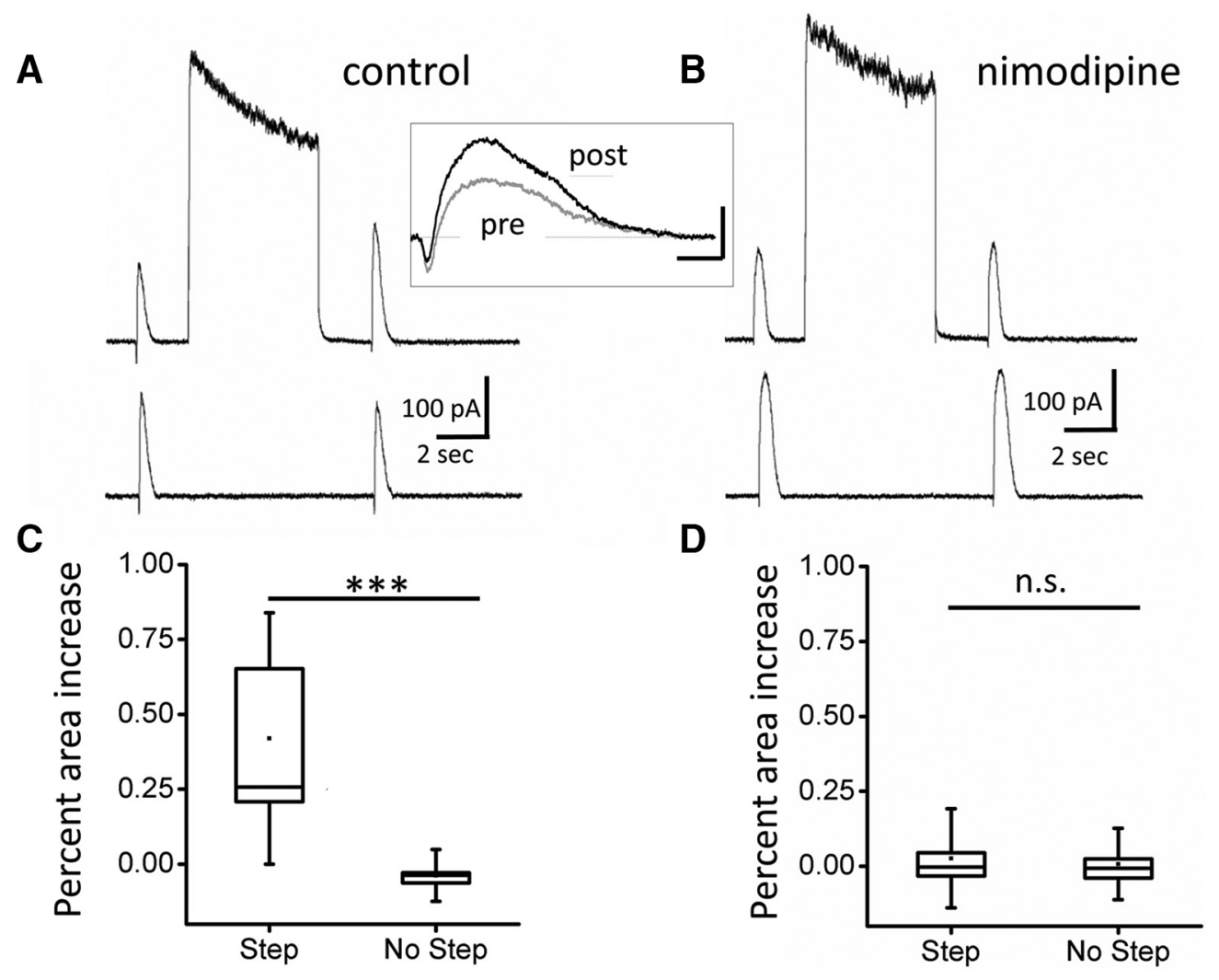

Figure 4. Effect of membrane depolarization on response to ACh puff. $A$, Voltage-clamp protocol to load synaptic cisterns. Puff of ACh interleaved with step to $-20 \mathrm{mV}$. Inset shows exemplar recordings. Scale bar, $100 \mathrm{pA}$ by $200 \mathrm{~ms}$. B, Same protocol in the presence of $10 \mu$ m nimodipine to inhibit $\mathrm{Ca}_{\mathrm{v}} 1.3$ calcium channels. With $\mathrm{Ca}_{\mathrm{v}} 1.3$ channels blocked, depolarization produced no change in the ACh-evoked current. C, Percentage increase in area of ACh response following the voltage step compared with that before the step. $n=19$ trials, 2 IHCs with step; $n=17$ trials, 2 IHCs no step. Means significantly different ${ }^{* * *}\left(t_{(34)}=6.59, p \ll 0.001\right)$ by paired $t$ test for equal variances. $D$, Percentage increase in area of ACh response before and after step in the presence of $10 \mu \mathrm{m}$ nimodipine. $n=23$ trials, $3 \mathrm{IHCs}$ with step; $n=25$ trials, $3 \mathrm{HHCs}$ no step, no significant difference between means. Box-and-whisker plots show upper, middle, and lower data quartiles (box), mean (dot), and SDs (whiskers).

A

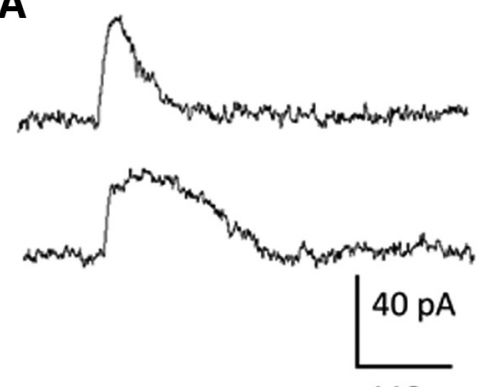

$112 \mathrm{~ms}$
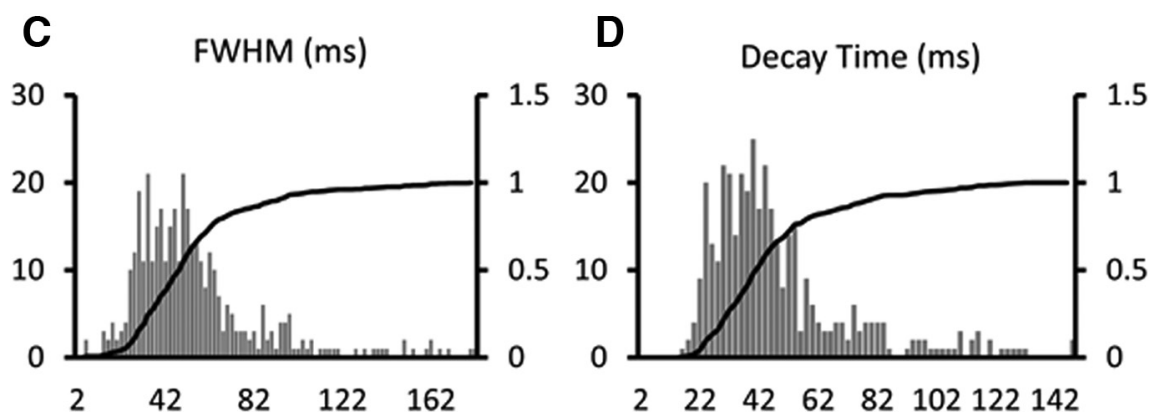

Figure 5. The shapes of IPSCS at $-40 \mathrm{mV}$ varied. $A$, Samples of IPSC waveform (spontaneous) in a P9 rat IHC recorded at -40 $\mathrm{mV}$. $\boldsymbol{B}$, Distribution of IPSC amplitudes $(n=384$ from $4 \mathrm{IHCs}$ ) at $-40 \mathrm{mV}$. Solid line shows cumulative fraction. C, Full-width duration at half amplitude (FWHM) for same dataset at $-40 \mathrm{mV}$. D, Decay time constant (single exponential) for IPSCs at $-40 \mathrm{mV}$. rical Gaussians, but rather skewed toward larger values (Fig. 5B-D). This waveform variability may reflect the activation of SK channels by calcium sources other than influx through the $\alpha 9 \alpha 10$-nAChRs. The synaptic morphology suggests a structural basis for calcium-source heterogeneity in the size and shape of associated cisterns (Fig. 1). In addition, cisterns may be more or less calcium-loaded if this depends on their proximity to voltage-gated calcium channels at ribbon synapses (Table 1). The small number of longer-lasting IPSCs (Fig. 5) are of particular interest since these became more common with enhanced calcium influx or release from stores (see below). The following experiments address the possibility that voltagegated calcium influx and the nearby synaptic cistern interact to modulate the waveform of efferent IPSCs.

IPSC waveforms vary with IHC membrane potential

IPSCs were recorded from IHCs held at $-60,-40$, and $-20 \mathrm{mV}$ (Fig. 6A). Postsynaptic currents include the outward flux of $\mathrm{K}$ ions through SK channels at 
these potentials (Glowatzki and Fuchs, 2000; Katz et al., 2004). As expected, because of the outward driving force on $\mathrm{K}$ ions, the amplitude of events increased with depolarization (Fig. 6B).

IPSCs also were longer lasting at depolarized membrane potentials. Statistically significant differences were observed in event duration at half amplitude [full width at half maximum (FWHM)], with events at $-60 \mathrm{mV}$ being the briefest and events at $-20 \mathrm{mV}$ being the longestlasting (Fig. 6C). The increased duration of IPSPs can be attributed to prolonged decay times; the average time constant of decay at $-20 \mathrm{mV}$ was nearly twice that at $-60 \mathrm{mV}$ (Fig. 6D). These changes in average IPSC decay time constant reflect the appearance of longer-lasting IPSCs that were rare at $-60 \mathrm{mV}$, but increasingly common with depolarization (see below).

Prolonged IPSCs suggest that a longerlasting cytoplasmic $\mathrm{Ca}^{2+}$ signal occurred at the efferent synapse in depolarized IHCs. This is unexpected if SK-channel gating occurs exclusively by $\mathrm{Ca}^{2+}$ ions entering through $\alpha 9 \alpha 10$-nAChRs. If $\alpha 9 \alpha 10$ nAChRs served as the only source of $\mathrm{Ca}^{2+}$, one would expect decay time constants to remain stable or even decrease due to the reduced inward driving force on $\mathrm{Ca}^{2+}$ ions at $-20 \mathrm{mV}$ compared with $-60 \mathrm{mV}$. Thus, experiments were designed to detect the contribution of other calcium sources to SK gating.

\section{Calcium entry through dihydropyridine-sensitive channels modulates IPSC waveforms}

Calcium action potentials occur in immature IHCs (Kros et al., 1998; Tritsch et al., 2007; Johnson et al., 2011). Under the present conditions, IHC membrane potential and cytoplasmic calcium (5 mM EGTA) were controlled, providing a baseline on which to examine voltage-gated influx. IHCs express $\mathrm{Ca}_{\mathrm{v}} 1.3$ voltage-gated calcium channels whose gating can be modulated by dihydropyridines. Nimodipine is an L-type voltage-gated calciumchannel blocker while Bay K 8644 (Bay K) is a positive modulator of L-type calcium-channel gating. IPSCs at $-40 \mathrm{mV}$ were recorded in the presence of $10 \mu \mathrm{M}$ nimodipine or $10 \mu \mathrm{M}$ Bay $\mathrm{K}$ (Fig. 7A). IPSC amplitudes were significantly smaller in nimodipine than in Bay $\mathrm{K}$ (Fig. $7 B$ ). $\mathrm{Ca}_{\mathrm{v}} 1.3$ modulators had still more substantial effects on IPSC time course. The half amplitude duration (FWHM) was reduced in nimodipine and prolonged in Bay $\mathrm{K}$ (Fig. 7C). Decay kinetics were similarly altered, with shorter time constants of decay in nimodipine and longer time constants of decay in Bay K (Fig. 7D). As in the previous experiments with altered membrane potential, enhanced calcium influx greatly increased waveform variability, seen as much larger "whiskers" for SD (Fig. 7C,D). Calcium that enters through L-type channels does not reach postsynaptic SK channels directly in these recordings since there was no slow increase in evoked or resting outward current (Fig. 4). Rather, it is as though voltage-gated calcium influx supplements the calcium signal produced by efferent ACh release.
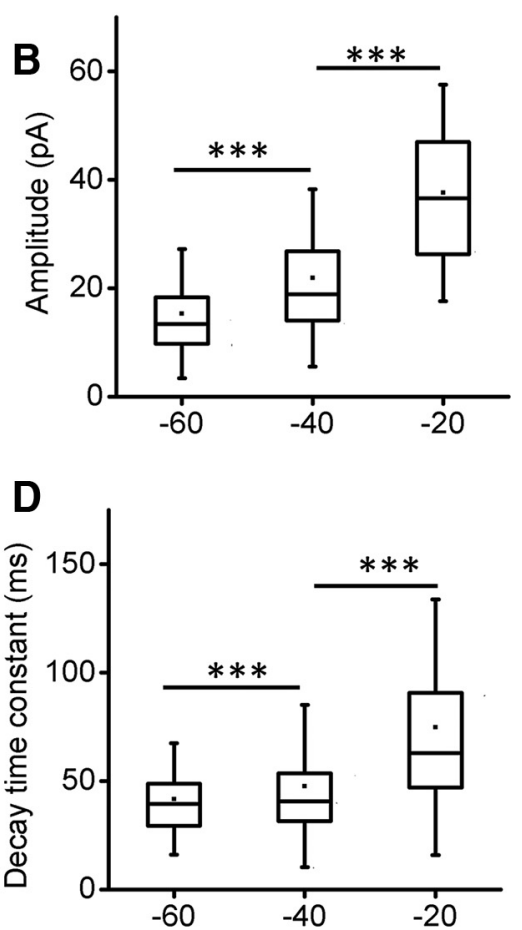

Figure 6. IPSC waveform varied with IHC membrane potential. $\boldsymbol{A}$, Examples of evoked and spontaneous IPSCS at labeled of -40 versus $-20 \mathrm{mV},{ }^{* * *} t_{(513)}=15.9, p \ll 0.001$. C, Average full width at half maximum amplitude (FWHM) for same ${ }^{* * *} t_{(366)}=4.99, p \ll 0.001$. Comparison of -40 versus $-20 \mathrm{mV},{ }^{* * *} t_{(432)}=8.99, p \ll 0.001$. Box-and-whisker plots show upper, middle, and lower data quartiles (box), mean (dot), and SDs (whiskers).

One possibility is that voltage-gated calcium loads the synaptic cistern, which then modulates the efferent response through calcium-induced calcium release.

\section{Calcium-induced calcium release prolongs IPSC duration}

Efferent synapses on hair cells, including immature IHCs (Figs. 1, 3 ) are noteworthy for their obligatory near-membrane postsynaptic cisterns. These cisterns are ideally positioned to play a role in postsynaptic $\mathrm{Ca}^{2+}$ handling and may regulate SK-channel gating via calcium-induced calcium release (CICR). Ryanodine is a CICR modulator that suppresses release at high concentrations $(\sim 100 \mu \mathrm{M})$ but potentiates it at low concentrations $(\sim 1 \mu \mathrm{M})$. IPSCs at $-40 \mathrm{mV}$ were recorded in the presence of $150 \mu \mathrm{M}$ ryanodine or $1 \mu \mathrm{M}$ ryanodine (Fig. 8). IPSC amplitudes were significantly smaller in $150 \mu \mathrm{M}$ ryanodine than in $1 \mu \mathrm{M}$ ryanodine (Fig. 8B).

Still larger effects were found on the duration of IPSCs recorded in potentiating and inhibiting concentrations of ryanodine. IPSCs were abbreviated by $150 \mu \mathrm{M}$ ryanodine while $1 \mu \mathrm{M}$ ryanodine gave rise to more frequent long-lasting IPSCs. The population data show that IPSC widths at half amplitude (FWHM) were shorter in $150 \mu \mathrm{M}$ ryanodine and longer in 1 $\mu \mathrm{M}$ ryanodine (Fig. $8 C$ ). Decay kinetics were altered similarly, with shorter decay time constants recorded in $150 \mu \mathrm{M}$ ryanodine and longer decay time constants recorded in $1 \mu \mathrm{M}$ ryanodine (Fig. 8D). These effects suggest that a ryanodine-sensitive calcium store, presumably the postsynaptic cistern, modulates the calcium signal evoked by ACh release from the efferent terminals. 

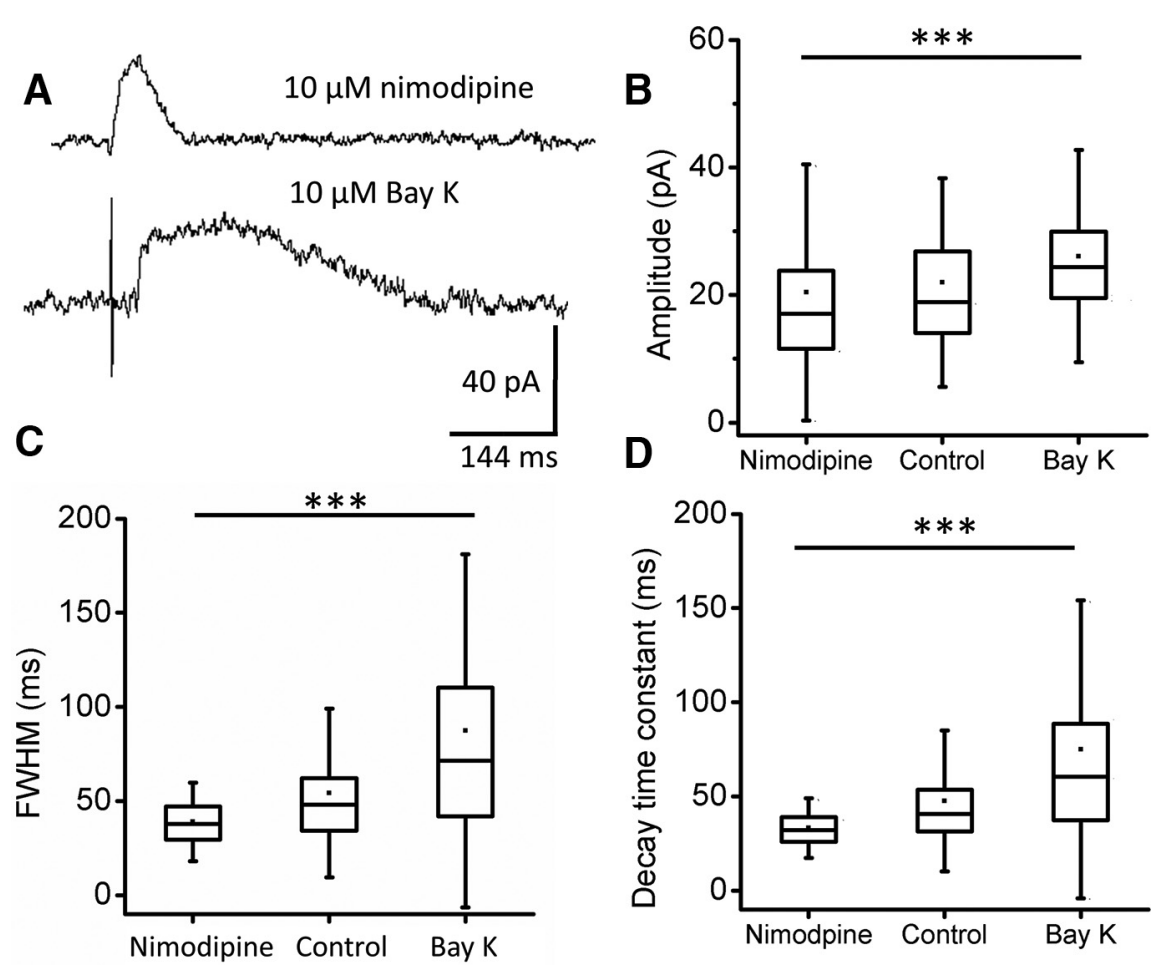

Figure 7. Voltage-gated calcium channels provide calcium for CICR. A, Sample IPSCs at $-40 \mathrm{mV}$ during inhibition (nimodipine) and facilitation (Bay K) of Ca 1 1.3-channel gating. $B$, Average IPSC amplitude in $10 \mu$ m nimodipine ( $n=432$ IPSCs from 5 IHCs) and $10 \mu \mathrm{m}$ Bay K ( $n=290$ IPSCs from 3 IHCS), ${ }^{* * *} t_{(689)}=6.19, p \ll 0.001$. C, Average duration at half-amplitude (FWHM) for IPSC dataset as in $\boldsymbol{B}$. Nimodipine versus Bay $K{ }^{* * *} t_{(308)}=12.96, p \ll 0.001$. D, Average time constant of decay for IPSC datasets as in $B$, nimodipine versus Bay $K{ }^{* * *} t_{(305)}=13.26, p \ll 0.001$. Box-and-whisker plots show upper, middle, and lower data quartiles (box), mean (dot), and SD (whiskers). Summarized control data from Figure 5 included for reference.

\section{IPSC enhancement by ryanodine is sensitive to dihydropyridines}

The effects of ryanodine and L-type calcium-channel modulators support the following hypothesis: that voltage-gated calcium influx feeds into cytoplasmic calcium stores, including the nearmembrane cistern, from which calcium-induced calcium release via ryanodine receptors modulates the efferent synaptic response. As a further test of this hypothesis, IPSCs recorded at $-40 \mathrm{mV}$ in $1 \mu \mathrm{M}$ ryanodine were then exposed to ryanodine plus $10 \mu \mathrm{M}$ nimodipine to block L-type VGCCs in the hair cell. As seen in the diary plot and averaged data (Fig. 9), nimodipine gradually reduced the effect of ryanodine on IPSC duration (FWHM). These extended recordings were compiled in two IHCs, showing a similar reduction in FWHM by nimodipine. However, $1 \mu \mathrm{M}$ ryanodine still increased the FWHM in cells previously exposed to nimodipine (Fig. 9C). The implication is that other sources of calcium can maintain the postsynaptic stores. Ryanodine acted quickly while nimodipine required as long as $15 \mathrm{~min}$ to achieve its maximal effect. In both experiments, the variance about the mean was greater for IHCs in ryanodine alone or when added to IHCs previously exposed to nimodipine.

\section{Contributions to variability in IPSC waveform}

IPSCs varied in amplitude and width at $-40 \mathrm{mV}$ (Fig. 5). The time course of SK current in quantal IPSCs (FWHM due to single vesicle release) is a direct indicator of the dynamics of hair cell calcium signaling during that event. FWHM increased with IHC depolarization, L-type channel gating, and facilitation of calciuminduced calcium release by ryanodine (Figs. 6, 7, 8, 9). A steep increase in variance accompanied the increase in the average
FWHM, seen as a spread to larger values as a fraction of the total (Fig. 10). The coefficient of variation (CV) of the FWHM increased progressively with IHC depolarization from -60 to -40 to $-20 \mathrm{mV}$ (Fig. 10B). The FWHM CV doubled as L-type channel gating was increased (Fig. 10C) or as CICR was enabled (Fig. 10D).

Why should the duration of IPSCs vary more under these conditions? One possibility is that vesicle sizes range widely and size distribution is uneven. However, this appears not to be the case. Efferent terminals themselves were small but contained hundreds of relatively uniform synaptic vesicles. The number of vesicles in six terminals on three different hair cells ranged from 243 to 944 ( $550 \pm 255$ SDs $)$. Vesicles within $1 \mu \mathrm{m}$ of the presynaptic plasma membrane were relatively uniform in size, distributed symmetrically about a mean diameter of $36.2 \pm 1.8 \mathrm{~nm}$ with CVs ranging from 0.12 to 0.15 , corresponding to volume variance of $0.36-0.45$. There were no significant differences in size or variability of vesicles computed independently for each of the six efferent terminals. In particular, there were no differences in efferent terminals situated near to or far from ribbons.

A more likely explanation is that the contribution of voltage-gated calcium flux to a ryanodine-sensitive store varies between the numerous efferent contacts on each IHC, affecting some more than others. Given the low probability of release overall, individual IPSCs are most likely to arise by release from different terminals and so reflect morphological or geographical features of each (Table 1). Efferent contacts were uniformly small, $\sim 1 \mu \mathrm{m}$ in maximum IHC contact on average. Postsynaptic cisterns had approximately half the appositional area (close contact with the plasma membrane) of efferent contacts and differed in shape. Most importantly, efferent synapses varied greatly in their proximity to ribbon synapses, the presumptive locus of voltage-gated calcium channels. The effects of membrane potential, dihydropyridines, and ryanodine could be explained if voltage-gated calcium influx serves as a source for loading the postsynaptic cistern. IPSCs from efferent contacts near ribbons will be affected by voltage-gated calcium influx, which loads the cistern, and by $1 \mu \mathrm{M}$ ryanodine, which promotes CICR from a loaded cistern. Those IPSCs due to release from isolated efferent contacts would result only from the calcium influx produced by a quantum of ACh. Thus, conditions that favor calcium storage and release will reveal functional heterogeneity among efferent contacts. When calcium influx is blocked, or stores are disabled, all synapses rely primarily on flux through $\alpha 9 \alpha 10$-nAChRs, and so function similarly.

\section{Discussion}

Before the onset of hearing, calcium spikes in IHCs drive glutamate release from ribbon synapses to excite type-I afferents. In this same period, IHCs are innervated by efferent neurons that release ACh to activate SK potassium channels, thereby hyperpolarizing and shunting the membrane to prevent transmitter 
release. Efferent and afferent contacts commingle on the IHC, presenting an opportunity to explore "calcium cross talk" between these opposing synaptic functions. A complementary study has demonstrated that calcium entry at efferent synapses is not likely to influence transmitter release at nearby ribbon synapses (Moglie et al., 2018), which is consistent with the hypothesis that efferent cisterns buffer postsynaptic calcium. The present work addresses questions concerning the opposite direction of calcium cross talk: from the afferent to the efferent synapse. These experiments show that prolonged voltage-gated calcium influx can contribute to the efferent activation of SK potassium channels, supporting the role of the cistern as a dynamic store capable of both uptake and release of calcium.

During the period of efferent innervation, immature IHCs have larger wholecell calcium currents than do mature IHCs (Marcotti et al., 2003) with more widely dispersed $\mathrm{Ca}_{\mathrm{v}} 1.3$ channels (Wong et al., 2013; Vincent et al., 2017) than those clustered tightly around ribbons in adult IHCs (Wichmann and Moser, 2015). These features of the immature IHC may be required to enable the IHC to influence the temporary efferent contacts. This synaptic cross talk fades as ribbon synapses mature with the onset of hearing and as efferent contacts are lost.

Could the calcium cross talk produced experimentally here also occur during postnatal maturation in vivo? Spontaneous calcium waves among the supporting cells of Kolliker's organ release ATP and potassium to cause seconds-long depolarization and calcium spike bursts in IHCs and consequent bursts of action potentials in spiral ganglion neurons (Tritsch et al., 2007; Wang and Bergles, 2015). This activity is thought to instruct the functional organization of the auditory system before the onset of hearing (Tritsch et al., 2010). IHC depolarization during a wave of excitation in Kolliker's organ lasts several seconds, similar to depolarizations used in the present experiments (Fig. 4). Efferent inhibition could be potentiated by Kolliker's organ-mediated depolarization and calcium action potentials that resupply synaptic calcium stores (Iosub et al., 2015). The spatiotemporal pattern of spontaneous cochlear activity would be sharpened by enhanced inhibition via the subsequent olivocochlear feedback. This hypothesis is consistent with the observation that $\alpha 9$-null mice, which lack functional efferent activity, have less well defined central tonotopy (Clause et al., 2014). This genetic model also suggests that there is reciprocity in synaptic regulation since IHC
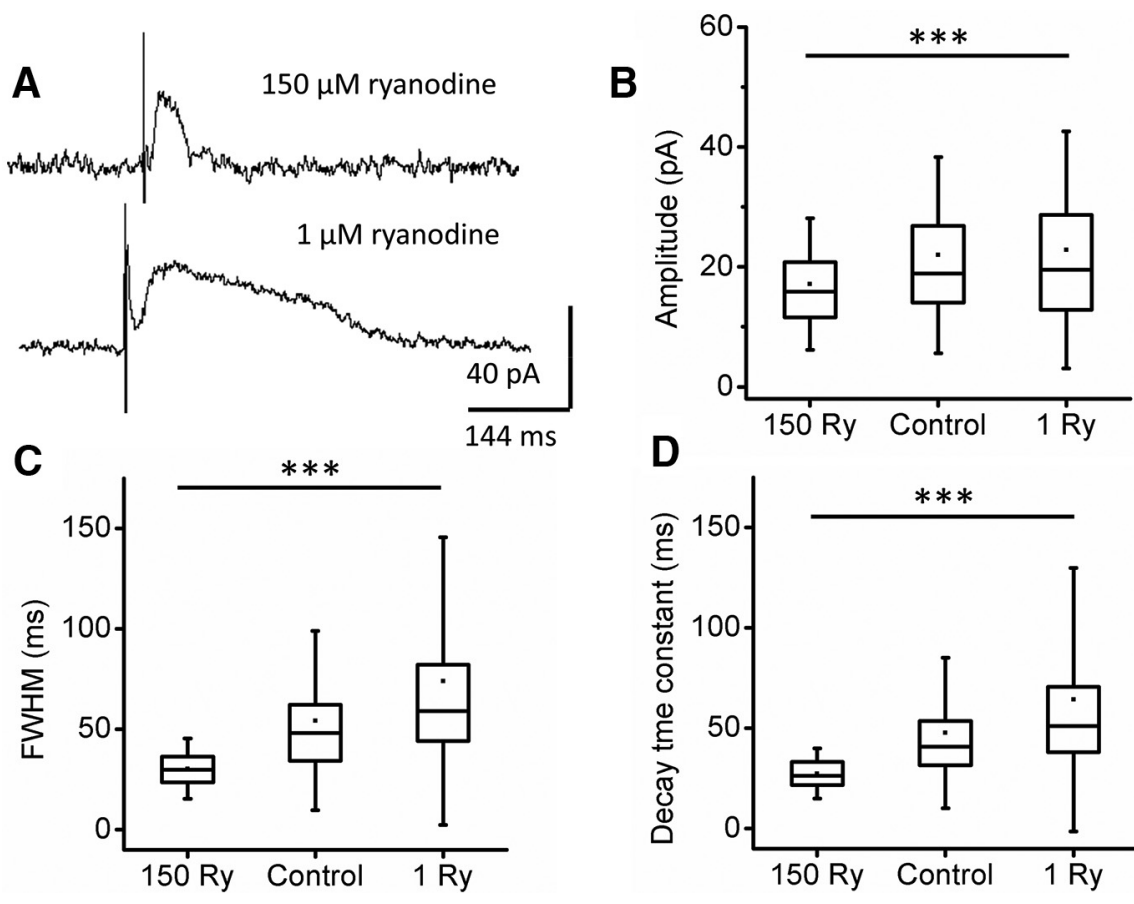

Figure 8. Ryanodine modulates efferent IPSCS. A, Sample IPSCS at $-40 \mathrm{mV}$ during treatment with an inhibiting $(150 \mu \mathrm{M})$ or facilitating $(1 \mu \mathrm{M})$ concentration of ryanodine. $\boldsymbol{B}$, Average amplitude of IPSCs in $150 \mu \mathrm{m}$ ryanodine ( $n=501$ IPSCs from 3 IHCS), 1 $\mu \mathrm{m}$ ryanodine $(n=388 \mathrm{IPSC}$ from $3 \mathrm{IHCS}),{ }^{* * *} t_{(569)}=7.69, p \ll 0.001$. C, Average full width at half-amplitude (FWHM) for the same IPSC datasets, ${ }^{* * *} t_{(569)}=7.7, p \ll 0.001$. D, Average time constant of decay for same IPSC datasets, ryanodine effects significantly different, ${ }^{* * *} t_{(409)}=16.36, p \ll 0.001$. Box-and-whisker plots show upper, middle, and lower data quartiles (box), mean (dot), and SDs (whiskers). Summarized control data from Figure 5 included for reference.

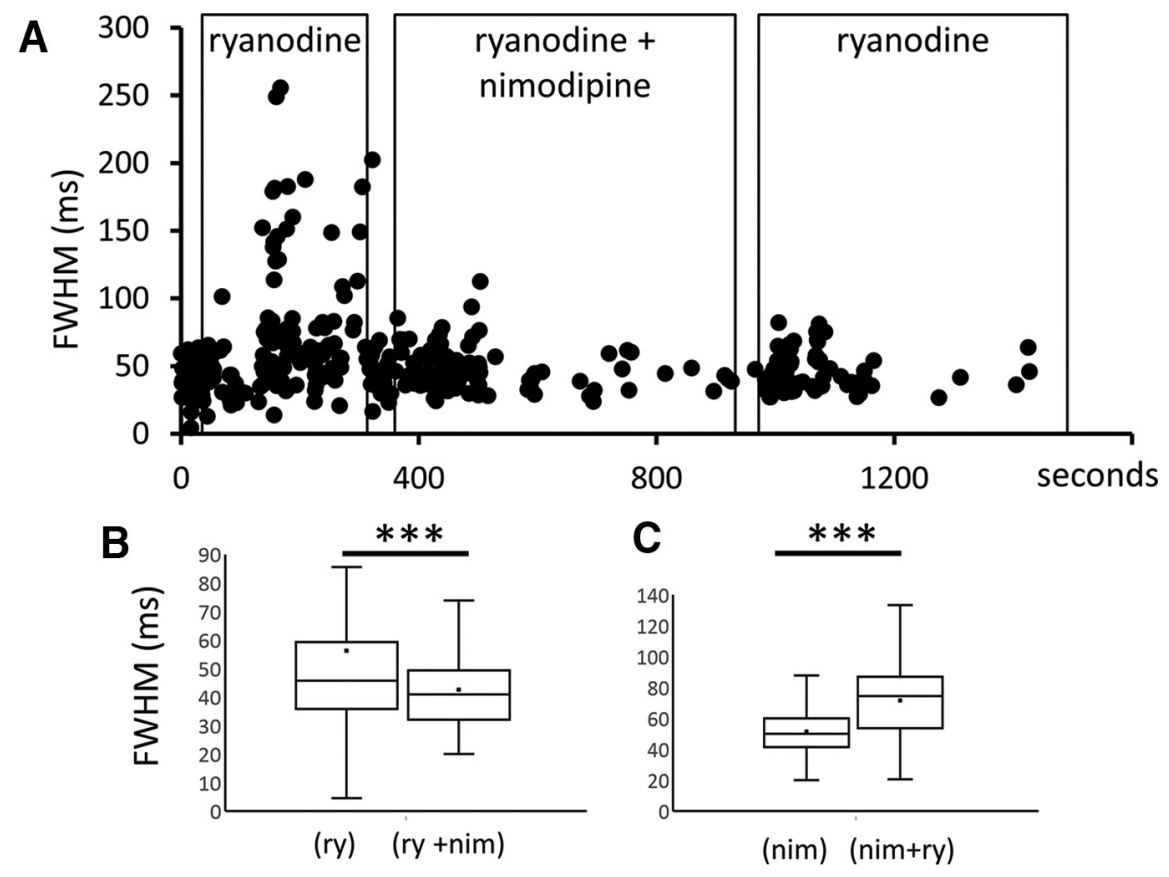

Figure 9. Interaction of ryanodine and nimodipine on IPSCS. A, Diary plot of IPSC FWHM during bath perfusion of $1 \mu \mathrm{M}$ ryanodine, ryanodine plus $10 \mu \mathrm{m}$ nimodipine, then ryanodine alone. $\boldsymbol{B}$, Average FWHM of IPSCS $(n=379)$ from two IHCs in ryanodine, then ryanodine plus nimodipine $(n=249),{ }^{* * *} t_{(494)}=6, p \ll 0.001$. C, Average FWHM of IPSCs from two IHCs in nimodipine $(n=582)$, then nimodipine plus ryanodine $(n=678),{ }^{* * *} t_{(582)}=17, p \ll 0.001$. Box-and-whisker plots show upper, middle, and lower data quartiles (box), mean (dot), and SDs (whiskers).

transmitter release remains immature in $\alpha 9$-null mice (Johnson et al., 2013).

Immature IHCs undergo comprehensive synaptic rearrangements before the onset of hearing. Clustering of calcium channels 

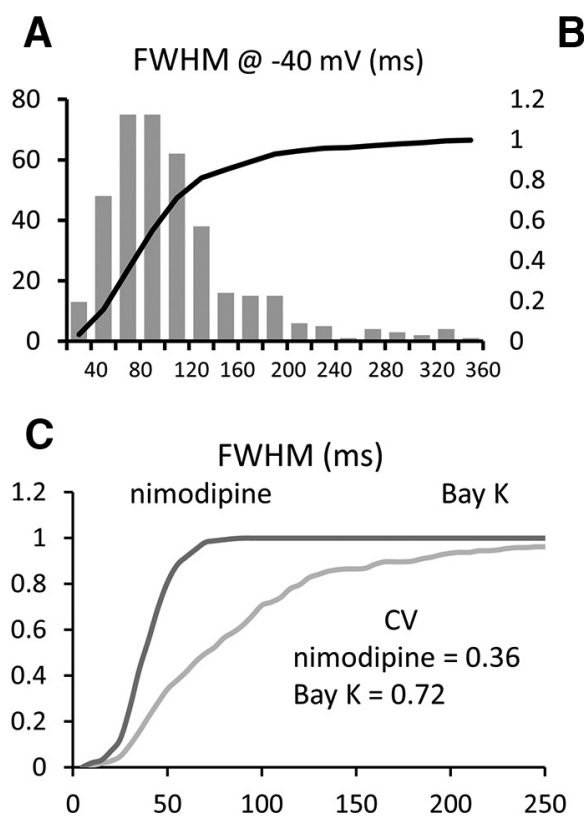

ryanodine and blockers of the endoplasmic calcium-ATPase (Lioudyno et al., 2004) and measurements in vivo suggest a role for calcium stores in efferent efficacy (Sridhar et al., 1995, 1997).

The present experiments show that calcium influx through $\alpha 9 \alpha 10$-nAChRs initiates efferent IPSCs in immature IHCs, but cisternal release of calcium can alter IPSC duration. Each IHC possesses 15-30 efferent synapses (Roux et al., 2011) with average minimal separation between ribbons and efferent contacts of $\sim 1.5 \mu \mathrm{m}$, comparable to values reported previously, e.g., $1.96 \mu \mathrm{m}$ (Ye et al., 2017). Given the variability of cisternal size and the range of distances from ribbon synapses reported here, the impact of cisternal storage and release of calcium should vary considerably among efferent contacts on a single IHC. In contrast, the membrane response to a vesicle's worth of ACh is likely to be relatively uniform, as indeed is the case for responses where CICR is blocked (Fig. 8) or when the response is recorded at 80 or $90 \mathrm{mV}$, when voltage-gated calcium influx is absent (Glowatzki and Fuchs, 2000; Katz et al., (Fig. 5). B, Cumulative fraction plots at three membrane potentials (data from Fig. 6). CV (SD/mean) for average duration at half amplitude (FWHM) of IPSCs. C, Cumulative fraction plots and CVs for IPSCs in L-type channel modulators. Data from Figure 7. D, Cumulative fraction plots and CVs for IPSCs in ryanodine. Data from Figure 8.

leads to more effective transmitter release (Johnson et al., 2005; Sendin et al., 2014) and efferent synapses first arise, then retract, in this 2 week window (Katz et al., 2004; Roux et al., 2011). Perhaps reflecting this transitional process, synaptic cisterns of IHCs at P9 are smaller than the efferent terminals (Fig. 1), which themselves cover only one-tenth as much IHC surface area as do the afferent contacts (Table 1). Although small in extent (membrane apposition), the volume of IHC cisterns is large relative to the volume of cytoplasm between the cistern and the immediate postsynaptic membrane where calcium enters through $\alpha 9 \alpha 10$ nAChRs (directly opposite active zones in the efferent terminal).

In these respects, cisterns in IHCs differ significantly from those of mature efferent synapses on OHCs. OHC cisterns form uninterrupted attachments to the plasma membrane that are coextensive with the larger presynaptic efferent terminals. Although larger in appositional area, $\mathrm{OHC}$ cisterns are uniformly flattened sacs (average luminal width, $\sim 20 \mathrm{~nm}$ ), so that their volume is only one-third larger than that of the underlying postsynaptic cytoplasm (Fuchs et al., 2014). Compared with the IHC, OHC cisterns appear designed to serve as barriers to cytoplasmic calcium. Thus, calcium-dependent potassium channels at $\mathrm{OHC}$ synapses (Wersinger et al., 2010; Rohmann et al., 2015) should be more comprehensively isolated from cytoplasmic calcium than those associated with the small, incomplete cisterns of IHCs. In addition, $\mathrm{OHCs}$ have many fewer ribbons and much smaller voltage-gated calcium currents (Knirsch et al., 2007; Beurg et al., 2008). Consequently, quantal efferent synaptic waveforms of OHCs should more directly reflect the time course of $\alpha 9 \alpha 10$ $\mathrm{nAChR}$ gating and be subject to little if any calcium store release. In keeping with that suggestion, IPSCs recorded at $-40 \mathrm{mV}$ in OHCs have shapes that vary much less than those of IHCs (Ballestero et al., 2011), with CV of 0.23 . This is not to say that synaptic cisterns in $\mathrm{OHCs}$ have no role at all in calcium regulation during longer-lasting efferent action. Seconds-long application of ACh in OHCs produced SK currents whose amplitude was altered by
2004; Gomez-Casati et al., 2005). Consistent with that observation, synaptic vesicles in efferent terminals were relatively uniform in size, $\sim 40 \mathrm{~nm}$ in diameter, with a CV ranging from 0.12 to 0.15 , as observed in other studies of mammalian neurons ( $\mathrm{Qu}$ et al., 2009). Consequently, one expects the vesicular volume to vary from 0.36 to 0.45 and so to produce a quantal ACh effect of similar variance under conditions where contributions from a store should be minimal. In $10 \mu \mathrm{m}$ nimodipine, the CV of amplitudes was 0.35 . In $150 \mu \mathrm{m}$ ryanodine, it was 0.43 . At $-60 \mathrm{mV}$, it was 0.49 . This is in reasonable agreement considering that the IPSC is a potassium current secondary to the initial gating of the $\alpha 9 \alpha 10$-nAChR.

Cisterns appear to be a ubiquitous feature of efferent-hair cell synaptic contacts, and cisternal synaptic structures can be found in other cells of the nervous system, such as spinal motor neurons (Nagy et al., 1993) and in hypothalamic nuclei (Hervás and Lafarga, 1979). These C (cistertnal) synapses are particularly interesting in the spinal cord, where they have been shown to be associated with cholinergic terminals and to undergo expansion in motor neuron disease (Pullen and Athanasiou, 2009). Similarly, efferents sprout and cisternal synapses are reformed on IHCs after excitotoxic insult (Pujol and Puel, 1999) and a reformation of efferent cisternal synapses occurs on IHCs of the C57BL/6 mouse during age-related hearing loss (Lauer et al., 2012; Zachary and Fuchs, 2015).

Regarding the loading of IHC cisterns, it is possible that they also can be loaded via calcium influx through $\alpha 9 \alpha 10$-nAChRs, as suggested by the effect of ryanodine in the presence of L-type channel block (Fig. 9). Prolonged application of ACh can overwhelm calcium homeostasis and cause transmitter release from the IHC (Moglie et al., 2018). However, under low release frequencies, such as the conditions in the present experiments, there was no impact of efferent calcium influx on afferent transmitter release. Rather, the present experiments show the opposite direction of flow; sustained calcium entry through $\mathrm{Ca}_{\mathrm{v}} 1.3$ channels can 
load efferent postsynaptic cisterns to alter inhibitory strength. Experiments with nimodipine show that even when IHCs are voltage clamped at $-40 \mathrm{mV}$, and relatively few $\mathrm{Ca}_{\mathrm{v}} 1.3$ channels are open, voltage-gated calcium contributes to IPSC waveforms. Moreover, IPSCs were most elongated at $-20 \mathrm{mV}$, where $\mathrm{Ca}_{\mathrm{v}} 1.3$ channels are near their highest open probability (Brandt et al., 2003; Zampini et al., 2010). The present results suggest that voltage-gated calcium enters the IHC and is sequestered in the subsynaptic cistern for future deployment upon efferent transmitter release. This mechanism produces greater inhibition at depolarized potentials, a feature that would not be present if the calcium signal giving rise to SK-channel activation arose only by influx through $\alpha 9 \alpha 10$-nAChRs. It should be noted that the present work asked only whether the postsynaptic cistern could function as a calcium store under a given set of experimental conditions, since this had not been thoroughly proven previously. To what extent this occurs in vivo will depend on the relative magnitude of influx and on the strength of mobile and fixed cytoplasmic calcium buffers. The native buffer in the synaptic region of young IHCs is equivalent to $2 \mathrm{~mm}$ BAPTA (Moglie et al., 2018), which would allow a higher resting level of free calcium than in the present recordings (5 mM EGTA). Cytoplasmic calcium buffers are in equilibrium with the various storage depots, including the synaptic cistern. This suggests that sufficient voltage-gated calcium influx could alter efferent synaptic time course in vivo.

The present results define calcium signals giving rise to IPSC waveforms and describe a form of postsynaptic efferent plasticity that encodes recent IHC depolarization. Calciuminduced calcium release not only enhances postsynaptic effects, but also can strengthen efferent transmission through nitricoxide-dependent retrograde facilitation (Kong et al., 2013). Such plasticity as well as other players (Wedemeyer et al., 2013; Ye et al., 2017) could participate in an interplay between afferent and efferent contacts during cochlear synaptogenesis. In contrast, maintained cisterns in mature OHCs may act primarily as sinks, segregating postsynaptic calcium signals from the wider cytoplasm. The role of the synaptic cistern as source or sink will depend on the degree to which it is loaded by cytoplasmic calcium (Fuchs, 2014) and so will vary among hair cells with different amounts of voltage-gated calcium influx and different degrees of calcium buffering. So, for example, IHCs from the cochlear base appear to have less capacity to buffer calcium than do apical IHCs (Johnson et al., 2017). This difference could encourage activitydependent afferent denervation and enhance the impact of returning efferent synapses.

\section{References}

Art JJ, Fettiplace R, Fuchs PA (1984) Synaptic hyperpolarization and inhibition of turtle cochlear hair cells. J Physiol 356:525-550. CrossRef Medline

Ashmore J, Russell J (1982) Effect of efferent stimulation on hair cells of the frog sacculus. J Physiol 329:25-26P.

Ballestero J, Zorrilla de San Martín J, Goutman J, Elgoyhen AB, Fuchs PA, Katz E (2011) Short-term synaptic plasticity regulates the level of olivocochlear inhibition to auditory hair cells. J Neurosci 31:14763-14774. CrossRef Medline

Beurg M, Safieddine S, Roux I, Bouleau Y, Petit C, Dulon D (2008) Calcium- and otoferlin-dependent exocytosis by immature outer hair cells. J Neurosci 28:1798-1803. CrossRef Medline

Brandt A, Striessnig J, Moser T (2003) CaV1.3 channels are essential for development and presynaptic activity of cochlear inner hair cells. J Neurosci. 23:10832-10840. CrossRef Medline

Clause A, Kim G, Sonntag M, Weisz CJ, Vetter DE, Rúbsamen R, Kandler K (2014) The precise temporal pattern of prehearing spontaneous activity is necessary for tonotopic map refinement. Neuron 82:822-835. CrossRef Medline

Dallos P, He DZ, Lin X, Sziklai I, Mehta S, Evans BN (1997) Acetylcholine, outer hair cell electromotility, and the cochlear amplifier. J Neurosci 17: 2212-2226. CrossRef Medline

Evans MG (1996) Acetylcholine activates two currents in guinea-pig outer hair cells. J Physiol 491:563-578. CrossRef Medline

Fiala JC (2005) Reconstruct: a free editor for serial section microscopy. Journal of microscopy 218:52-61. CrossRef Medline

Flock A, Russell I (1976) Inhibition by efferent nerve fibres: action on hair cells and afferent synaptic transmission in the lateral line canal organ of the burbot lota lota. J Physiol 257:45-62. CrossRef Medline

Fuchs PA (2014) A 'calcium capacitor' shapes cholinergic inhibition of cochlear hair cells. J Physiol 592:3393-3401. CrossRef Medline

Fuchs PA, Murrow BW (1992) Cholinergic inhibition of short (outer) hair cells of the chick's cochlea. J Neurosci 12:800-809. CrossRef Medline

Fuchs PA, Lehar M, Hiel H (2014) Ultrastructure of cisternal synapses on outer hair cells of the mouse cochlea. J Comp Neurol 522:717-729. CrossRef Medline

Glowatzki E, Fuchs PA (2000) Cholinergic synaptic inhibition of inner hair cells in the neonatal mammalian cochlea. Science 288:2366-2368. CrossRef Medline

Gomez-Casati ME, Fuchs PA, Elgoyhen AB, Katz E (2005) Biophysical and pharmacological characterization of nicotinic cholinergic receptors in rat cochlear inner hair cells. J Physiol 566:103-118. CrossRef Medline

Goutman JD, Fuchs PA, Glowatzki E (2005) Facilitating efferent inhibition of inner hair cells in the cochlea of the neonatal rat. J Physiol 566:49-59. CrossRef Medline

He DZ, Dallos P (1999) Development of acetylcholine-induced responses in neonatal gerbil outer hair cells. J Neurophysiol 81:1162-1170. CrossRef Medline

Hervás JP, Lafarga M (1979) Subsurface cisterns in paraventricular nuclei of the hypothalamus of the rat. Cell Tissue Res 199:271-279. CrossRef

Housley GD, Ashmore JF (1991) Direct measurement of the action of acetylcholine on isolated outer hair cells of the guinea pig cochlea. Proc Biol Sci 244:161-167. CrossRef Medline

Iosub R, Avitabile D, Grant L, Tsaneva-Atanasova K, Kennedy HJ (2015) Calcium-induced calcium release during action potential firing in developing inner hair cells. Biophys J 108:1003-1012. CrossRef Medline

Johnson SL, Marcotti W, Kros CJ (2005) Increase in efficiency and reduction in $\mathrm{Ca} 2+$ dependence of exocytosis during development of mouse inner hair cells. J Physiol 563:177-191. CrossRef Medline

Johnson SL, Franz C, Knipper M, Marcotti W (2009) Functional maturation of the exocytotic machinery at gerbil hair cell ribbon synapses. J Physiol 587:1715-1726. CrossRef Medline

Johnson SL, Eckrich T, Kuhn S, Zampini V, Franz C, Ranatunga KM, Roberts TP, Masetto S, Knipper M, Kros CJ, Marcotti W (2011) Positiondependent patterning of spontaneous action potentials in immature cochlear inner hair cells. Nat Neurosci 14:711-717. CrossRef Medline

Johnson SL, Wedemeyer C, Vetter DE, Adachi R, Holley MC, Elgoyhen AB, Marcotti W (2013) Cholinergic efferent synaptic transmission regulates the maturation of auditory hair cell ribbon synapses. Open Biol 3:130163. CrossRef Medline

Johnson SL, Olt J, Cho S, von Gersdorff H, Marcotti W (2017) The coupling between $\mathrm{Ca}^{2+}$ channels and the exocytotic $\mathrm{Ca}^{2+}$ sensor at hair cell ribbon synapses varies tonotopically along the mature cochlea. J Neurosci 37 : 2471-2484. CrossRef Medline

Katz E, Elgoyhen AB, Gómez-Casati ME, Knipper M, Vetter DE, Fuchs PA, Glowatzki E (2004) Developmental regulation of nicotinic synapses on cochlear inner hair cells. J Neurosci 24:7814-7820. CrossRef Medline

Knirsch M, Brandt N, Braig C, Kuhn S, Hirt B, Münkner S, Knipper M, Engel $\mathrm{J}$ (2007) Persistence of $\mathrm{Ca}_{\mathrm{v}} 1.3 \mathrm{Ca}^{2+}$ channels in mature outer hair cells supports outer hair cell afferent signaling. J Neurosci 27:6442-6451. CrossRef Medline

Kong JH, Zachary S, Rohmann KN, Fuchs PA (2013) Retrograde facilitation of efferent synapses on cochlear hair cells. J Assoc Res Otolaryngol 14:1727. CrossRef Medline

Kros CJ, Ruppersberg JP, Rüsch A (1998) Expression of a potassium current in inner hair cells during development of hearing in mice. Nature 394: 281-284. CrossRef Medline

Lauer AM, Fuchs PA, Ryugo DK, Francis HW (2012) Efferent synapses return 
to inner hair cells in the aging cochlea. Neurobiol Aging 33:2892-2902. CrossRef Medline

Lioudyno M, Hiel H, Kong JH, Katz E, Waldman E, Parameshwaran-Iyer S, Glowatzki E, Fuchs PA (2004) A "synaptoplasmic cistern" mediates rapid inhibition of cochlear hair cells. J Neurosci 24:11160-11164. CrossRef Medline

Marcotti W, Johnson SL, Rusch A, Kros CJ (2003) Sodium and calcium currents shape action potentials in immature mouse inner hair cells. J Physiol 552:743-761. CrossRef Medline

Moglie MJ, Fuchs PA, Elgoyhen AB, Goutman JD (2018) Compartmentalization of antagonistic $\mathrm{Ca}(2+)$ signals in developing cochlear hair cells. Proc Natl Acad Sci U S A 115:E2095-E2104. CrossRef Medline

Nagy JI, Yamamoto T, Jordan LM (1993) Evidence for the cholinergic nature of C-terminals associated with subsurface cisterns in alpha-motoneurons of rat. Synapse 15:17-32. CrossRef Medline

Oliver D, Klöcker N, Schuck J, Baukrowitz T, Ruppersberg JP, Fakler B (2000) Gating of $\mathrm{Ca}^{2+}$-activated $\mathrm{K}+$ channels controls fast inhibitory synaptic transmission at auditory outer hair cells. Neuron 26:595-601. CrossRef Medline

Pujol R, Carlier E, Devigne C (1978) Different patterns of cochlear innervation during the development of the kitten. J Comp Neurol 177:529-536. CrossRef Medline

Pujol R, Carlier E, Devigne C (1979) Significance of presynaptic formations in early stages of cochlear synaptogenesis. Neurosci Lett 15:97-102. CrossRef Medline

Pujol R, Puel JL (1999) Excitotoxicity, synaptic repair, and functional recovery in the mammalian cochlea: a review of recent findings. Ann N Y Acad Sci 884:249-254. CrossRef Medline

Pullen AH, Athanasiou D (2009) Increase in presynaptic territory of C-terminals on lumbar motoneurons of G93A SOD1 mice during disease progression. Eur J Neurosci 29:551-561. CrossRef Medline

Qu L, Akbergenova Y, Hu Y, Schikorski T (2009) Synapse-to-synapse variation in mean vesicle size and its relationship with synaptic morphology and function. J Comp Neurol 514:343-352. CrossRef Medline

Rohmann KN, Wersinger E, Braude JP, Pyott SJ, Fuchs PA (2015) Activation of BK and SK channels by efferent synapses on outer hair cells in high-frequency regions of the rodent cochlea. J Neurosci 35:1821-1830. CrossRef Medline

Roux I, Wersinger E, McIntosh JM, Fuchs PA, Glowatzki E (2011) Onset of cholinergic efferent synaptic function in sensory hair cells of the rat cochlea. J Neurosci 31:15092-15101. CrossRef Medline

Sendin G, Bourien J, Rassendren F, Puel JL, Nouvian R (2014) Spatiotemporal pattern of action potential firing in developing inner hair cells of the mouse cochlea. Proc Natl Acad Sci U S A 111:1999-2004. CrossRef Medline

Shnerson A, Devigne C, Pujol R (1981) Age-related changes in the C57BL/6J mouse cochlea. II. Ultrastructural findings. Brain Res 254:77-88. Medline

Simmons DD (2002) Development of the inner ear efferent system across vertebrate species. J Neurobiol 53:228-250. CrossRef Medline

Simmons DD, Mansdorf NB, Kim JH (1996) Olivocochlear innervation of inner and outer hair cells during postnatal maturation: evidence for a waiting period. J Comp Neurol 370:551-562. CrossRef Medline
Sridhar TS, Liberman MC, Brown MC, Sewell WF (1995) A novel cholinergic "slow effect" of efferent stimulation on cochlear potentials in the guinea pig. J Neurosci 15:3667-3678. CrossRef Medline

Sridhar TS, Brown MC, Sewell WF (1997) Unique postsynaptic signaling at the hair cell efferent synapse permits calcium to evoke changes on two time scales. J Neurosci 17:428-437. CrossRef Medline

Sugai T, Yano J, Sugitani M, Ooyama H (1992) Actions of cholinergic agonists and antagonists on the efferent synapse in the frog sacculus. Hear Res 61:56-64. CrossRef Medline

Tritsch NX, Yi E, Gale JE, Glowatzki E, Bergles DE (2007) The origin of spontaneous activity in the developing auditory system. Nature 450:5055. CrossRef Medline

Tritsch NX, Rodríguez-Contreras A, Crins TT, Wang HC, Borst JG, Bergles DE (2010) Calcium action potentials in hair cells pattern auditory neuron activity before hearing onset. Nat Neurosci 13:1050-1052. CrossRef Medline

Vincent PF, Bouleau Y, Charpentier G, Emptoz A, Safieddine S, Petit C, Dulon D (2017) Different $\mathrm{Ca}_{\mathrm{v}} 1.3$ channel isoforms control distinct components of the synaptic vesicle cycle in auditory inner hair cells. J Neurosci 37:2960-2975. CrossRef Medline

Wang HC, Bergles DE (2015) Spontaneous activity in the developing auditory system. Cell Tissue Res 361:65-75. CrossRef Medline

Wedemeyer C, Zorrilla de San Martín J, Ballestero J, Gómez-Casati ME, Torbidoni AV, Fuchs PA, Bettler B, Elgoyhen AB, Katz E (2013) Activation of presynaptic $\mathrm{GABA}_{\mathrm{B}(1 \mathrm{a}, 2)}$ receptors inhibits synaptic transmission at mammalian inhibitory cholinergic olivocochlear-hair cell synapses. J Neurosci 33:15477-15487. CrossRef Medline

Wersinger E, McLean WJ, Fuchs PA, Pyott SJ (2010) BK channels mediate cholinergic inhibition of high frequency cochlear hair cells. PloS One 5:e13836. CrossRef Medline

Wichmann C, Moser T (2015) Relating structure and function of inner hair cell ribbon synapses. Cell Tissue Res 361:95-114. CrossRef Medline

Wong AB, Jing Z, Rutherford MA, Frank T, Strenzke N, Moser T (2013) Concurrent maturation of inner hair cell synaptic $\mathrm{Ca}^{2+}$ influx and auditory nerve spontaneous activity around hearing onset in mice. J Neurosci 33:10661-10666. CrossRef Medline

Ye Z, Goutman JD, Pyott SJ, Glowatzki E (2017) mGluR1 enhances efferent inhibition of inner hair cells in the developing rat cochlea. J Physiol 595: 3483-3495. CrossRef Medline

Zachary SP, Fuchs PA (2015) Re-emergent inhibition of cochlear inner hair cells in a mouse model of hearing loss. J Neurosci 35:9701-9706. CrossRef Medline

Zampini V, Johnson SL, Franz C, Lawrence ND, Münkner S, Engel J, Knipper M, Magistretti J, Masetto S, Marcotti W (2010) Elementary properties of $\mathrm{CaV} 1.3 \mathrm{Ca}(2+)$ channels expressed in mouse cochlear inner hair cells. J Physiol 588:187-199. CrossRef Medline

Zorrilla de San Martín J, Pyott S, Ballestero J, Katz E (2010) $\mathrm{Ca}^{2+}$ and $\mathrm{Ca}^{2+}$ activated $\mathrm{K}^{+}$channels that support and modulate transmitter release at the olivocochlear efferent-inner hair cell synapse. J Neurosci 30:1215712167. CrossRef Medline 